Short reports

\title{
Does erythropoietin accelerate malignant transformation in multiple myeloma?
}

\author{
A Olujohungbe, S Handa, J Holmes
}

\begin{abstract}
Summary
Growth factors or humoral agents can support haemopoiesis in various bone marrow disorders. They have the ability to act on multiple cell lineages and in myeloid cells, and the potential to act on the neoplastic equivalent of normal cells. Anaemia is a common feature of multiple myeloma seen in at least two-thirds of patients at presentation. Erythropoietin is increasingly being used with variable effect for the treatment of this anaemia, especially in cases associated with renal failure and in patients in whom blood transfusion may be undesirable or contraindicated. We describe a patient treated with recombinant erythropoietin who developed fulminating malignant transformation. The demonstration of erythropoietin receptors on a human myeloma cell line and the occurrence of the rare complication of plasma cell leukaemia in our patient stresses the need for caution and invites detailed clinical and laboratory studies before its general use.
\end{abstract}

Keywords: erythropoietin, malignant transformation, multiple myeloma

MRC Myeloma Trials Office, Department of Immunology, University of Birmingham, Birmingham B15 2TT, UK

A Olujohungbe

\section{Department of} Haematology, Sandwell District Hospital, Lyndon, West Bromwich B71 4HJ, UK

S Handa

\section{Department of} Haematology, Queen Elizabeth Hospital, Birmingham, B15 2TH UK

J Holmes

Correspondence to Dr A Olujohungbe, Department of Haematology, University Hospital of South

Manchester, Nell Lane,

West Didsbury, Manchester

M20 8LR, UK

Accepted 1 May 1996
Multiple myeloma is a malignant disease of bone marrow plasma cells with an incidence of over 2000 new cases annually in England and Wales. ${ }^{1}$ Anaemia (haemoglobin $<11 \mathrm{~g} / \mathrm{dl}$ ) is a common and well documented feature occurring in $50-60 \%$ of newly diagnosed patients. The aetiology is multifactorial and successful treatment with chemotherapy and attainment of stable disease usually results in its correction and alleviation of transfusion requirements.

There have been several reports in the literature on the use and efficacy of growth factors, predominantly erythropoietin, in the treatment of anaemia due to myelomatosis. ${ }^{2-5}$ Two reports in the literature have briefly raised questions regarding the safety of recombinant erythropoietin on disease progression. ${ }^{3,4} \mathrm{We}$ describe a third case of disease progression with a temporal association with the use of recombinant erythropoietin which stresses the need for caution in its use and invites further study on its effect on malignant transformation.

\section{Case report}

A 62-year-old man presented to his general practitioner with mild pain in the chest wall following a fall. He was previously well. Investigations revealed a haemoglobin of 11.7 $\mathrm{g} / \mathrm{dl}$, white cell count $3.6 \times 10^{9} / \mathrm{l}$, neutrophils $1.9 \times 10^{9} / \mathrm{l}$, platelets $95 \times 10^{9} / 1$, normal serum calcium, renal and liver function. There were no fractures or lytic lesions seen on skeletal survey. He was found to have an IgG kappa paraprotein of $10 \mathrm{~g} / \mathrm{l}$, normal serum beta $2^{-}$ microglobulin and no Bence Jones proteinuria. He had solitary cysts of both kidneys detected incidentally on ultrasonography but histologically benign. Bone marrow aspirate showed $20 \%$ abnormal plasma cells. He was reluctant to have treatment and was placed under periodic review.

Five months later, he developed progressive marrow failure and was commenced on $\mathrm{ABCM}$ combination chemotherapy comprising six-weekly intravenous adriamycin and bisnitrosurea $30 \mathrm{mg} / \mathrm{m}^{2}$, respectively, day 1 ; melphalan $6 \mathrm{mg} / \mathrm{m}^{2}$ and cyclophosphamide $100 \mathrm{mg} / \mathrm{m}^{2}$ orally on days $22,23,24$ and 25 as per the 8th MRC myelomatosis trial protocol. Blood counts failed to recover four weeks after completion of one course of $\mathrm{ABCM}$ and a bone marrow showed a hypocellular marrow with patchy residual disease. He was started on weekly cyclophosphamide orally $\left(400 \mathrm{mg} / \mathrm{m}^{2}\right)$ for a total period of five months until stable disease was attained, with blood and platelet support as required. He developed platelet refractoriness and red cell allo-antibodies necessitating HLA matched platelet and red cell transfusions every three weeks.

After three months of increasing difficulty with blood components support, he was commenced on recombinant erythropoietin by continuous subcutaneous infusion at a dose of $150 \mathrm{IU} / \mathrm{kg} /$ day three times a week (total dose 13 $000 \mathrm{IU} /$ day) to reduce his transfusion requirements. His blood pressure was 170/110 $\mathrm{mmHg}$, and haemoglobin $8.6 \mathrm{~g} / \mathrm{dl}$ on institution. There was no improvement in blood counts or the level of support required over the next three months and the dose was increased to $200 \mathrm{IU} / \mathrm{kg} /$ day (total dose $16800 \mathrm{IU} /$ day) with the same frequency of administration.

Four weeks later, he presented to the casualty department with vague abdominal pain. Abdominal ultrasonography showed an encysted left intrarenal haemorrhage measuring $8 \mathrm{~cm}$ in diameter. Renal function was deranged (urea $9.6 \mu \mathrm{mol} / 1$ and serum creatinine $171 \mathrm{mmol} / \mathrm{l})$, full blood profile showed a haemoglobin of $12.6 \times 10^{9} \mathrm{~g} / \mathrm{dl}$, elevated white cell count at $15.9 \times 10^{9} / 1$, platelets of $29 \times 10^{9} / 1$ and a blood plasma cell count of $3.2 \times 10^{9} / 1$. 
Morphology was consistent with circulating plasmablasts and a diagnosis of secondary plasma cell leukaemia was made. His erythropoietin therapy was stopped.

Bone marrow aspirate revealed infiltration with $98 \%$ abnormal plasma cells with large prominent nucleoli. A central venous catheter was inserted and he was started on VAMP (vincristine, adriamycin, cyclophosphamide and methylprednisolone). He deteriorated and died 14 days later of overwhelming tumour load and progressive renal failure.

\section{Discussion}

Anaemia is an important pretreatment prognostic factor in multiple myeloma. Its treatment includes blood transfusions, tumour cytoreduction and, recently, erythropoietin. To date, approximately 80 patients with myelomatosis treated with erythropoietin have been reported. The response is variable and may be related to number and sensitivity of erythropoietin receptors on erythroid precursors $^{6}$ or levels of endogenous erythropoietin production. ${ }^{2}$ Some patients with normal renal function have demonstrated a good response to recombinant erythropoietin, implying that a renal deficiency in erythropoietin secretion may not solely explain the anaemia at presentation. ${ }^{2}$

A variety of cytokines have been implicated in myeloma cell growth both in vitro and in vivo. An increase in serum IL-6 (interleukin-6) levels has been consistently reported in patients with active myelomatosis compared to patients with stable multiple myeloma. ${ }^{7}$ Granulocyte macrophage colony stimulating factor, IL-3 and IL-5 synergise with IL-6 to support myeloma cell line proliferation in culture. ${ }^{8}$ Granulocyte macrophage colony stimulating factor, granulocyte colony stimulating factor and IL-3 receptors have also been demonstrated on the surface of acute nonlymphocytic leukaemia blasts but their response to growth factors was very heterogenous and bore no correlation to receptor numbers or surface expression. ${ }^{11}$

Interestingly, a phase III randomised clinical trial in elderly patients with acute myoblastic

1 MacLennan ICMM, Drayson $M$, Dunn J. Current issues in cancer. Multiple myeloma. BMf 1994; 308: 1033 -6.

2 Ludwig H, Fritz E, Kotzmann H,Hocker P, Gisslinger H, Barnas U. Erythropoietin treatment of anaemia associated with multiple myeloma. $N$ Engl f Med 1990; 322: 1693-9.

3 Caillette A, Barreto S, Gimenez E, Labeeuw M, Zech P. Is erythropoietin treatment safe and effective in myeloma patients receiving haemodialysis? Clin Nephrol 1993; 40: $176-8$.

4 Rogers S, Russell NH, Morgan AG. Effect of erythropoietin in patients with myeloma. BMf 1990; 301: 667 .

5 Barlogie B, Beck T. Recombinant human erythropoietin and the anaemia of multiple myeloma. Stem Cells 1993; 11: 88-94.

6 Aoki I, Nishijima K, Homori M, Nakahara K, Higashi K Ishikawa K. Responsiveness of bone marrow erythroid progenitors to recombinant human erythropoietin in vitro in multiple myeloma. Br $₹$ Haematol 1992; 81: 463-9.

7 Klein BJ, Zhang XG, Jourdan M, et al. Paracrine but not autocrine regulation of myeloma cell growth and differentiation by interleukin-6. Blood 1991; 73: 517

8 Zhang XG, Bataille R, Jourdan M, et al. Granulocyte macrophage colony stimulating factor synergizes with interleukin- 6 in supporting proliferation of human myelom cells. Blood 1990; 76: 2599-605.

\section{Learning points}

- recombinant erythropoietin receptors have been detected on myeloma cell lines but detailed studies have not been conducted on fresh bone marrow myeloma samples

- recombinant erythropoietin may mobilise normal human progenitor cells into peripheral blood, and it is possible it may have the same effect on myeloma precursors

leukaemia demonstrated an improved survival in the granulocyte macrophage colony stimulating factor and chemotherapy arm $(p=0.035)$ despite the above laboratory findings. ${ }^{12}$ Rogers et $a l^{4}$ described a patient with Bence Jones myeloma who showed a marked increase in light chain excretion associated with erythropoietin therapy which decreased on cessation of therapy. Also, Caillette et $a l^{3}$ reported an early relapse in their patient four weeks after starting erythropoietin therapy .

Expression of the erythropoietin receptor has been demonstrated on a human myeloma cell line. ${ }^{9}$ In addition, there may be increased concentration and cycling of marrow progenitor cells in peripheral blood following treatment with recombinant erythropoietin. ${ }^{10}$ Although erythropoietin treatment was well tolerated by our patient for a period of four months, he developed a plasma cell leukaemia, a rare form of disease acceleration seen in only $1-2 \%$ of multiple myeloma patients. We are unable to prove a causal association and this transformation may be part of the natural history of myelomatosis. The recent increase in dose may suggest a dose-dependent relationship in malignant transformation of an earlier plasma cell precursor. There is an increasing indication for the use of erythropoietin in anaemia due to myelomatosis by patients who have severe renal failure or are Jehovah's witnesses. We therefore feel that it is important to highlight the potential dangers of the use of this cytokine under these circumstances.

The increasing number of reports only serves to strengthen the relationship.

9 Okuno Y, Takahashi T, Susuki A, et al. Expression of the erythropoietin receptor on a human myeloma cell line. Biochem Biophys Res Commun 1990; 170: 1128-34.

10 Dessypris EN, Graber SE, Krantz DB, Stone WJ. Effects of recombinant erythropoietin on the concentration and cycling status of human haemopoietic progenitor cells in vivo. Blood 1988; 72: 2060-5.

11 Park LS, Waldron PE, Friend D, et al. Interleukin-3, GMCSF, and G-CSF receptor expression on cell lines and primary leukaemia cells: receptor heterogeneity and relationship to growth factor responsiveness. Blood 1989; 74: tionship

12 Rowe J.M, Andersen J, Mazza JJ, et al. Phase III randomized placebo controlled study of granulocyte-macrophage colony stimulating factor in adult patients (55-70 years) with acute myelogenous leukaemia. A study of the Eastern Cooperative Oncology Group (ECOG). Blood 1993; 82 (suppl): 329a. 